\title{
Bicyclo [6.3.0] Undecane Sesquiterpenoids: Structures, Biological Activities, and Syntheses
}

\author{
Guo-Fei Qin ${ }^{1,2,3,{ }^{\dagger}}$, Hong-Bao Liang ${ }^{1,+}{ }^{+}$Wen-Xiu Liu ${ }^{4,+}$, Feng Zhu ${ }^{1}$, Ping-Lin Li ${ }^{2,3}$, \\ Guo-Qiang $\mathrm{Li}^{2,3, *(1)}$ and Jing-Chun Yao ${ }^{1, *}$ \\ 1 State Key Laboratory of Generic Manufacture Technology of Chinese Traditional Medicine, \\ Lunan Pharmaceutical Group Co. Ltd., Linyi 273400, China; qinguofei@126.com (G.-F.Q.); \\ lianghongbao1985@163.com (H.-B.L.); nwzf@nwafu.edu.cn (F.Z.) \\ 2 Key Laboratory of Marine Drugs, Chinese Ministry of Education, School of Medicine and Pharmacy, \\ Ocean University of China, Yushan Road 5, Qingdao 266003, China; lipinglin@ouc.edu.cn \\ 3 Laboratory of Marine Drugs and Biological Products, National Laboratory for Marine Science and \\ Technology, Qingdao 266235, China \\ 4 Jiangsu Hengrui Pharmaceutical Co. Ltd., Lianyungang 222002, China; liuwenxiu08@126.com \\ * Correspondence: liguoqiang@ouc.edu.cn (G.-Q.L.); yaojingchun@lunan.cn (J.-C.Y.); \\ Tel.: +86-532-8203-2323 (G.-Q.L.); +86-539-503-0319 (J.-C.Y.); Fax: +86-532-8203-3054 (G.-Q.L.); \\ $+86-539-503-0800$ (J.-C.Y.) \\ + These authors contributed equally to this work.
}

Academic Editor: Derek J. McPhee

Received: 24 September 2019; Accepted: 30 October 2019; Published: 30 October 2019

\begin{abstract}
Sesquiterpenoids constitute a marvelously varied group of natural products that feature a vast array of molecular architectures. Among them, the unusual bicyclo [6.3.0] undecane sesquiterpenoids are one of the most representative. To date, only approximately 42 naturally occurring compounds with this unique scaffold, which can be classified into seven different groups, have been reported. As the first-found member of each type, dactylol, asteriscanolide, dumortenol, toxicodenane $\mathrm{C}$, and capillosanane $\mathrm{S}$ are characteristic of the four methyl groups on the five-eight-membered ring system. Only 11-hydroxyjasionone and sinuketal decorate the core with an isopropyl group. These natural products exhibit a wide range of bioactivities, including antifouling, anti-inflammatory, immune suppression, cytotoxic, antimutagenic, antiplasmodial, and antiviral activities. It was noted that some total syntheses of precapnellane-sesquiterpenoids (dactylol, poitediol, precapnelladiene), asteriscanolide, and 11-hydroxyjasionone have been achieved, because their cyclooctanoid core represents an important target for the development of synthetic strategies to prepare eight-membered ring-containing compounds. This review focuses on these natural sesquiterpenoids and their biological activities and synthesis, and aims to provide a foundation for further research of these interesting compounds.
\end{abstract}

Keywords: sesquiterpenoids; bicyclo [6.3.0]; five-eight-membered ring; cyclooctane; structures; biological activities; syntheses

\section{Introduction}

In the past thirty years, nature has played a significant role in the discovery of new drugs. Meanwhile, many natural products with interesting skeletons have been reported from terrestrial and marine sources [1-4]. Sesquiterpenoids, a group of naturally occurring 15-carbon isoprenoids, are widely distributed secondary metabolites in nature and show a vast array of interesting molecular architectures [5-8]. Among them, the unusual bicyclo [6.3.0] undecane sesquiterpenoids are one of the most representative. To the best of our knowledge, since dactylol was isolated from the sea hare Aplysia 
dactylomela in 1977 [9], only seven types of scaffolds of bicyclo [6.3.0] undecane sesquiterpenoids have been reported (Figure 1). Structurally, precapnellane (Figure 1a), asteriscane (Figure 1b), dumortane (Figure 1c), toxicodenane (Figure 1d), and capillosane (Figure 1e) featured four methyl groups on the 5-8 ring moiety, while jasionane (Figure 1f) and sinulane (Figure 1g) decorate the core with an isopropyl group. As the cyclooctanoid core represents an important and challenging target for the development of the methodology, necessary to prepare the eight-membered ring-containing compounds, some total syntheses of precapnellane-sesquiterpenoid [10-29], asteriscane-sesquiterpenoid [30-36], and jasionane-sesquiterpenoid [37] have been achieved. However, so far, no comprehensive review of these molecules has been published. To provide a foundation for further research, this review summarizes the structures, biological activities, and chemical synthesis of bicyclo [6.3.0] undecane sesquiterpenoids.

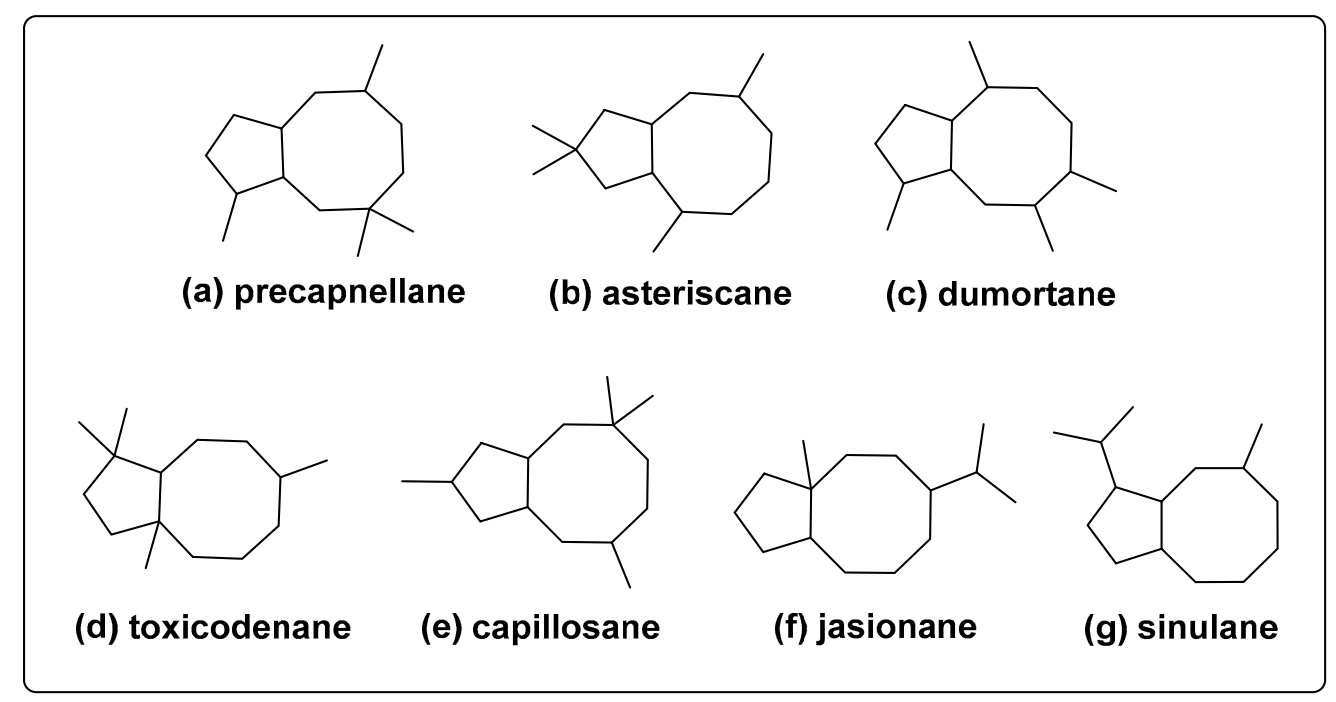

Figure 1. Carbon skeletons of bicyclo [6.3.0] sesquiterpenoids (a-g).

\section{Four Methyl Type Bicyclo [6.3.0] Undecane Sesquiterpenoids}

\subsection{Precapnellane-Sesquiterpenoid}

In 1977, the first bicyclo [6.3.0] undecane sesquiterpenoid, named dactylol (1, Figure 2), was reported in the Caribbean sea hare Aplysia dactylomela by Schmitz's group [9]. Its absolute configuration was derived from the CD data of a substituted cyclopentanone degradation product, which is a chemical conversion compound. In its structure, as the cyclooctanoid core represents an important and challenging target [10] for preparing the eight-membered ring-containing compounds, dactylol, an exemplary member of this class, has been widely synthesized (in total) by synthetic chemists. In order to construct the necessary carbon-carbon bonds, both Paquette's group and Gadwood's group used a [3,3] sigmatropic rearrangement strategy from 1985 to 1987 [10-12]. On the other hand, in the Paquette route, a cycooctadiene ring was built from cycloheptane precursors by Friedel-Crafts cyclization, while the Gadwood route featured an anionic oxy-Cope rearrangement. Later, to solve the undesired isomer problem, originatingthe stereoselective functional group transformations, Feldman et al. developed concise and stereoselective novel $[6 \pi+2 \pi]$ intramolecular photocycloaddition to synthesize dactylol in 1989 and 1990 [13,14]. Then, in 2000, intramolecular $4+3$ cycloaddition was achieved in the synthesis of dactylol by Harmata's group [15,16]. In 1996, ring-closing metathesis was used to synthesize dactylol by Fürstner et al. [17], and Vanderwal's group further developed this strategy [18]. Molandar's team reported the concise, nonracemic synthesis of dactyol utilizing a novel [3 + 5] annulation approach in 1995 [19]. 


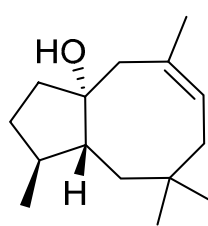

1 , dactylol

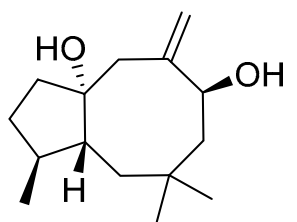

2, poitediol

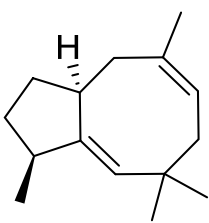

3, precapnelladiene

Figure 2. Structures of precapnellane-sesquiterpenoids.

In 1978, dactylol (1), together with poitediol (2), whose structure was determined by X-ray crystallography, was found in the seaweed Laurencia poitei (Lamouroux) Howe by Fenical's group [38]. Gadwood's group and Vanderwal's group also used their strategy to achieve the total synthesis of compound $2[10,18,20,21]$.

One year later, Djerassi's group reported the isolation of precapnelladiene (3) from the nonpolar fractions of the soft coral Capnella imbricata [39]. To establish its stereochemistry, Mehta and Murty synthesized precapnelladiene (3) through tricyclo [6.3.0.0 $\left.0^{2,6}\right]$ undecane via ruthenium-catalyze oxidation [22,23]. The Claisen rearrangement strategy was also used as a prelude for the preparation of compound 3 by Paquette's group and Petasis's group [24-26]. Moore et al. also reported the total synthesis of precapnelladiene (3) through the oxy-Cope rearrangement [27,28]. In 2007, Iguchi's group reported an enantioselective copper-catalyzed [2+2]-cycloaddition reaction to obtain compound 3 [29].

\subsection{Asteriscane-Sesquiterpenoid}

In 1985, San Feliciano and colleagues reported the first asteriscane type sesquiterpenoid, named asteriscanolide (4), from the hexane extract of plant Asteriscus aquaticus [40]. Its structure was determined by $\mathrm{X}$-ray diffraction. The enantioselective total synthesis of asteriscanolide (4) was achieved in 1988 by Wender et al. based on nickel-catalysed intramolecular [4 +4] cycloaddition [30]. In 2000, the Michael-Michael reaction sequence and ring-closing metathesis were used as the key bond-forming operations to synthesize compound 4 by Paquette's group [31], and in the same year Krafft and colleagues published on the total synthesis of $( \pm)$-asteriscanolide by a intermolecular Pauson-Khand [2+2+1] cycloaddition reaction as the key transformation [32,33]. Additionally in 2000, Snapper's group developed an efficient synthesis of $( \pm)-4$ using sequential intramolecular cyclobutadiene cycloaddition, ring-opening metathesis, and Cope rearrangement reactions [34]. In 2011, Yu's group described the total synthesis of (+)-4 using a chiral ene-vinylcyclopropane substrate induced Rhodium(I)-catalyzed [(5+2) +1$]$ cycloaddition reaction to construct a 5-8 ring core $[35,36]$.

Additionally in 1985, two asteriscane analogues 1,10,7,8-tetradehydro-asteriscanolide (5, Figure 3) and methyl-3 $\alpha, 5 \alpha, 8 \alpha, 10 \alpha H$-asteriscan-15-oate (6, Figure 3 ) were found in the species $A$. graveolens by Bohlmann's group [41].

In 1995 and 1999, in the plant Lippia integrifolia, a traditional medicine of north and central Argentina, Catalán's group and König's group reported two new asteriscane sesquiterpenes $3 \alpha$-hydroxy-6-asteriscene (7, Figure 3) [42] and asterisca-3(15),6-diene (8, Figure 3) [43], respectively.

The first marine originating asteriscane sesquiterpene, asterisca-2(9),6-diene (9, Figure 3), was isolated from the marine animal aeolid nudibranch Phyllodesmium magnum by Guo et al. in 2011 [44]. Based on the predator-prey relationship between P. magnum and the soft coral genus of Sinularia, the source of compound 9 may be soft coral [44-46].

In 2013, fourteen new asteriscane-type sesquiterpenoids (capillosananes A-N) (10-23, Figure 3) (the first large-scale discovery of bicyclo [6.3.0] undecane sesquiterpenoids) were found in the soft coral S. capillosa by Lin's group [45]. Their absolute configurations were determined by Mosher's method (compounds 10, 11, 14, 19), CD rules (compounds 13, 16-18, 23), ECD calculation (compounds 16 and 17), biogenetic consideration (compound 15), and chemical conversion (compounds 10, 16, 20, 22). In bioassay tests, these compounds were inactive against HCT-8, HePG2, BGC-823, A549, and SKOV3 human humor cell lines. Nevertheless, compounds $\mathbf{1 1}$ and $\mathbf{1 8}$ exhibited weak in vitro 
inhibitory effects on inflammation-related TNF- $\alpha$. Compound $\mathbf{1 0}$ showed potent antifouling activity against Balanus amphitrite with an $\mathrm{IC}_{50}$ value of $9.70 \mu \mathrm{M}$, whereas the value of compound 18 was $54 \mu \mathrm{M}$. A capillosanane D derivative (also from the genus of Sinularia (S. verruca)), named deoxocapillosanane D (24, Figure 3), was isolated by Yan and coworkers in 2016 [46], but it showed no anti-HIV-1 or anti-inflammatory activities.<smiles>C[C@H]1CCC[C@@H]2C(=O)O[C@@H]3C(C)(C)C[C@H](C1=O)[C@]23O</smiles>

4, asteriscanolide<smiles>C/C1=C/CC[C@H](C)C2=C(C1)CC(C)(C)C2</smiles>

9<smiles>CC1=CC23OC2(CC(C)(C)CC3C)C(=O)C1O</smiles>

10 , capillosanane A<smiles>CC1=CC2=C(CC(C)(C)C2=O)[C@@H](C)CCC1=O</smiles>

14, capillosanane $E$ 15, capillosanane $F$<smiles>CC1CCC2(O)OC3(C=C[C@]1(C)O2)CC(C)(C)[C@@H]3O</smiles><smiles>CC1=CC2(O)CC(C)(C)CC23OC1(O)CCC3C</smiles><smiles>COC(=O)[C@H]1CCC[C@@H](C)C(=O)[C@H]2CC(C)(C)C[C@]12C</smiles>

6<smiles>C/C1=C/C2=C(CC(C)(C)[C@H]2O)[C@H](C)CC[C@@H]1O</smiles>

11, capillosanane $B$<smiles>CC1=CC2=CC(C)(C)CC2(O)C(C)CC[C@@H]1O</smiles>

16, capillosanane $\mathbf{G}$<smiles>CC1=CC23CC(C)(C)CC(O)(C(C)CCC(O2)O3)C1(C)O</smiles>

19 , capillosanane J 20, capillosanane K 21, capillosanane $L$<smiles>C/C1=C/CC[C@H](C)[C@H]2CC(C)(C)C[C@H]2C1</smiles>

7<smiles>C/C1=C/C2=C(CC(C)(C)[C@H]2O)[C@@H](C)CC[C@@H]1O</smiles>

12, capillosanane $\mathrm{C}$<smiles>CC1=CC2=CC(C)(C)CC2(O)C(C)CC[C@@H]1O</smiles>

17, capillosanane $\mathrm{H}$<smiles>CC1=CC2=CC(C)(C)C[C@]23O[C@H](CC[C@H]3C)O1</smiles>

22, capillosanane $M$<smiles>C=C1CC/C=C(/C)C[C@H]2CC(C)(C)C[C@H]12</smiles>

8<smiles>C/C1=C/C2=C(CC(C)(C)C2=O)[C@@H](C)CC[C@@H]1O</smiles>

13, capillosanane D<smiles>CC1CC[C@]2(O)O[C@]3(CC(C)(C)C(=O)C3=C[C@@]2(C)O)O1</smiles>

18, capillosanane I<smiles>CC1(C)C/C2=C/[C@](C)(O)[C@](C)(O)CC[C@](C)(O)[C@@]2(C)C1</smiles>

23, capillosanane $\mathrm{N}$<smiles>C/C1=C/C2=C(CC(C)(C)C2)C(C)CC[C@@H]1O</smiles>

24, deoxocapillosanane D<smiles>C[C@H]1CCC[C@H]2C(=O)O[C@@H]3C(C)(C)C=C(C1=O)[C@@]23O</smiles>

25, wilfolide A<smiles>C[C@H]1CCC[C@@H]2C(=O)O[C@H]3C2[C@H]1CC3(C)C</smiles>

26 , wilfolide $B$<smiles>CC1(O)CCC[C@H]2C(=O)O[C@H]3C(C)(C)C[C@@H](C1=O)[C@]32C</smiles>

27 , asteriscanolidenol

Figure 3. Structures of asteriscane-sesquiterpenoids.

In the search for bioactive compounds in the roots of Cynanchum wilfordii, two new asteriscane type sesquiterpenoid wilfolides A and B (25 and 26, Figure 3) were isolated and identified by Zhao's group in 2015 [47]. Their absolute configurations were elucidated by X-ray crystallography with $\mathrm{Cu}$ $\mathrm{K} \alpha$ radiation. Compound 25 exhibited weak inhibitory effect against acetylcholinesterase.

A chemical examination of the aerial parts of the Asteriscus graveolens subsp. stenophyllus. by León et al. in 2016 resulted in the isolation of asteriscanolidenol (27, Figure 3), a new sesquiterpene lactone of the asteriscanolide type [48]. Unfortunately, this lactone showed no cytotoxicity effects against the HL-60 and MOLT-3 leukemia cell lines.

\subsection{Dumortane-Sesquiterpenoid}

The first dumortane sesquiterpenoid, dumortenol (28, Figure 4), was isolated from the diethyl ether extract of Argentinian liverwort Dumortiera hirsuta by Toyota and coworkers in 1997 [49]. The stereochemical assignments of $\mathbf{2 8}$ were clarified by X-ray crystallographic analysis (crystals 
were obtained from the methanol solution). In 1999, their reinvestigation of a new collection of Argentine D. hirsuta led to the isolation of two new dumortane derivatives (29 and 30), together with nor-dumortane sesquiterpene 31 [50].<smiles>C=C1CCC2C(=C)CC[C@H](C)/C(C)=C\C12</smiles>

28, dumortenol<smiles>CC1=CC2(C)CCCC2[C@H](C)OCC[C@@H]1C</smiles>

32, capillosanane $\mathbf{W}$<smiles>CC1=CC2=C(C)C(=O)C[C@H]2[C@@H](C)CC[C@@H]1C</smiles>

29<smiles>CC(=O)C[C@H]1C(C)=C2OC2(C)[C@@H](C)CC[C@H]1C</smiles>

30<smiles>C[C@H]1CC[C@@H](C)C(=O)C=C2[C@H]1CCC2(C)O</smiles>

31

Figure 4. Structures of dumortane-sesquiterpenoids.

Compound 28 was also obtained from soft coral Sinularia capillosa by Duh's group in 2010, which is the first report of this type of sesquiterpenoid in a marine organism [51]. In 2014, chemical examination of the same soft coral species was carried out by Lin's group and resulted in the isolation of two dumortane analogues, capillosananes W and X (32 and 33, Figure 4) [52]. The absolute configuration of 32 was determined via the $\mathrm{CD}$ data of the in situ complex of the tertiary alcohol with $\mathrm{Rh}_{2}\left(\mathrm{OCOCF}_{3}\right)_{4}$ by applying the bulkiness rule; 33 was assumed to be the same as $\mathbf{3 2}$ from biogenetic consideration. Bioactive assays indicated that compound 32 has anti-inflammatory effects with an inhibitory rate of $34 \%$ (at $10 \mu \mathrm{M}$, the positive control NK007 with inhibitory rates of $46 \%$ at $100 \mathrm{nM}$ ).

In 2014, Shen's group reported only one microorganism-originated bicyclo [6.3.0] undecane sesquiterpenoid, named tuberculariol D from a mutant strain G-444 of Tubercularia sp. TF5 isolated from the inner bark of Taxus mairei (34, Figure 4) [53]. At $30 \mu \mathrm{g} / \mathrm{disc}$, this compound exhibited no antifungal activities against Candida albicans.

\subsection{Toxicodenane-Sesquiterpenoid}

In 2013, toxicodenanes C (35, Figure 5) was obtained from the dried resin of Toxicodendron vernicifluum by Cheng's group [54]. This compound showed significantly inhibitory effects with a dose- and time-dependent relationship on fibronectin, collagen IV, and IL-6 in high-glucose-induced mesangial cells, which means that it has potential in treating diabetic nephropathy.

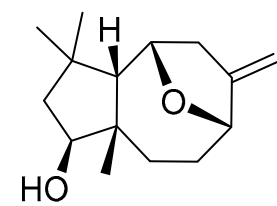

35, toxicodenane C

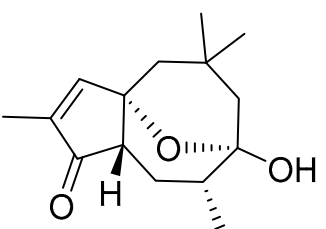

36, capillosanane $S$

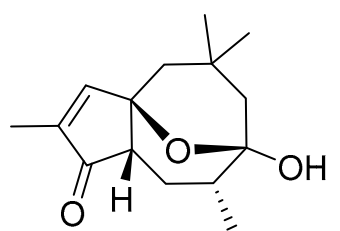

37, capillosanane T

Figure 5. Structures of toxicodenane-sesquiterpenoids and capillosane-sesquiterpenoids.

\subsection{Capillosane-Sesquiterpenoid}

One year later, Lin's group reported capillosananes S and T (36 and 37, Figure 5) from the soft coral S. capillosa [52]. The absolute configuration of compound $\mathbf{3 6}$ was determined by the octant rule for cyclopentenones and further supported by the ECD method; compound 37 was only determined by 
the octant rule. Unfortunately, these compounds were not active in cytotoxic (HCT-8, HePG2, BGC-823, A549, SKOV3) and pathogenetic microorganism assays.

\section{Isopropyl Type Bicyclo [6.3.0] Undecane Sesquiterpenoids}

Isopropyl type bicyclo [6.3.0] undecane sesquiterpenoids are rare in nature. By the end of August 2019, only 5 isopropyl type bicyclo [6.3.0] undecane sesquiterpenoids (far fewer than the four methyl type) have been reported. This may be due to the difficulty for diverse biogenic pathways to form a 5-8 fused ring in nature. As shown in Scheme 1, the plausible biosynthetic pathways of bicyclo [6.3.0] undecane sesquiterpenoids were proposed. The carbon skeletons of the four methyl type bicyclo [6.3.0] sesquiterpenoids can be carried out by cyclization reaction and Wagner-Meerwein rearrangements from the farnesyl diphosphate (FPP) [54,55]. However, an unexpected cycloheptane to cyclooctane ring expansion process [56], a key step, may determine the occurrence rate of isopropyl type bicyclo [6.3.0] undecane sesquiterpenoids.

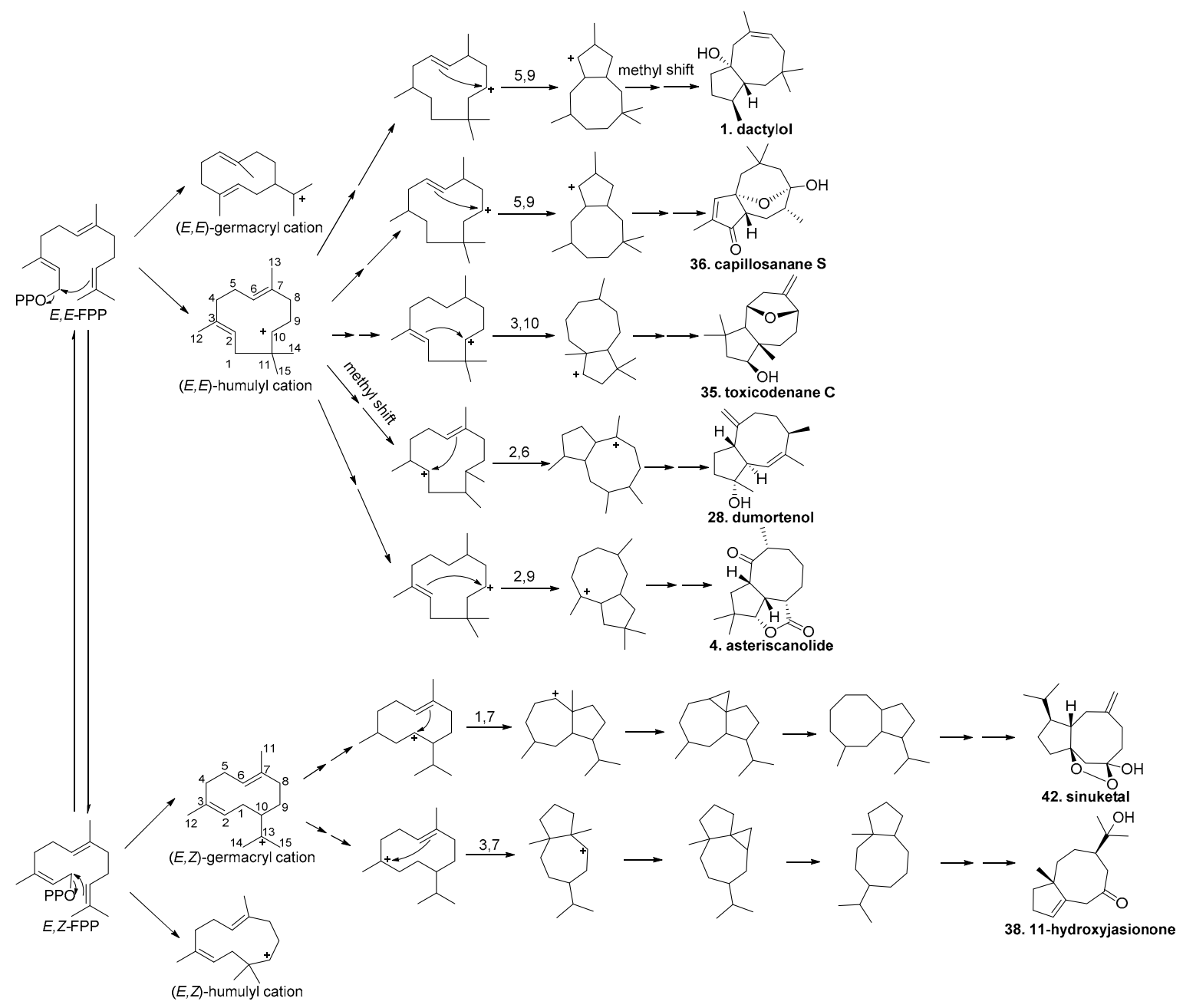

Scheme 1. The plausible biosynthetic pathway of bicyclo [6.3.0] undecane sesquiterpenoids.

\subsection{Jasionane-Sesquiterpenoid}

The first isopropyl-branched bicyclo [6.3.0] undecane sesquiterpenoid, named 11-hydroxyjasionone (38), was isolated from the aerial parts of the Jasonia montana plant by Ahmed et al. in 1988 [57]. It was first synthesised in 1994 by Trost and Parquette, using a TMM (2-(1-(trimethylsilyl)-1-cyclopropyl) allyl pivalate) cycloaddition strategy through fragmentation of the [3.3.0] system to form a 5-8-fused bicyclic core [37]. 
In the following year, Rustaiyan and coworkers isolated a new jasionane type sesquiterpene lactone tehranolide (39, Figure 6) from the aerial parts of Artemisia diffusa [58]. As there is an endoperoxide pharmacophore like the antimalarial agent artemisinin in the molecule, some bioactivity test works on compound 39 [59-65] and the fractions containing it [66,67] have been done by Iranian scientists. In summary, tehranolide (39) has a variety of biological activities, including modulating the immune response by reducing regulatory $\mathrm{T}$ cell $[59,60]$, inhibiting proliferation of MCF-7, HeLa, and K562 cells [61-63], against chemical mutagens in Salmonella strains [63], and inhibiting the growth of Plasmodium falciparum $[64,65]$.<smiles>CC1(O)CCC2(C)CCC=C2CC(=O)C1</smiles>

38, 11-hydroxyjasionone

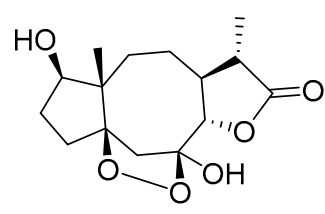

39 , tehranolide

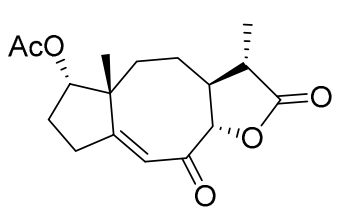

40, arvestolide $B$

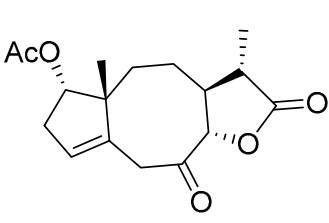

41, arvestolide C

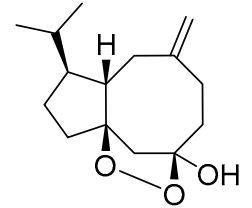

42, sinuketal

Figure 6. Structures of jasionane-sesquiterpenoids and sinularia-sesquiterpenoids.

In 2013, chemical investigations of the aerial parts of another Artemisia specie A. vestita by Tian et al. led to the isolation of two new jasionane sesquiterpenes: Arvestolides B and C (40 and 41, Figure 6) [68]. The absolute configuration of compound $\mathbf{4 0}$ was determined by single-crystal X-ray diffraction with $\mathrm{Cu} \mathrm{K} \alpha$ radiation, and the absolute configuration of compound 41 was the same as compound 40 based on biogenetic consideration and comparing its optical rotation with $\mathbf{4 0}$. Compound 40 showed a moderate inhibitory effect on lipopolysaccharide (LPS)-induced nitric oxide (NO) production in BV-2 microglial cells.

\subsection{Sinulane-Sesquiterpenoid}

In 2018, Li's team found the first example of marine-originated isopropyl type bicyclo [6.3.0.] undecane sesquiterpenoid sinuketal (42, Figure 6) from soft coral Sinularia sp. [56]. Its relative and absolute configurations were determined on the basis of the NOESY spectrum in combination with a conformational analysis, density functional theory-NMR, and the TDDFT/ECD method. Compared with the similar analogue compound 39, the positions of the methyl and isopropyl groups of compound 42 were quite different. The biological activity tests showed that $\mathbf{4 2}$ displayed antiviral activities (against influenza A viruses H1N1 and PR8, with $\mathrm{IC}_{50}$ values of 172 and $443 \mu \mathrm{M}$, respectively), weak cytotoxic activities (toward Jurkat, MDA-MB-231, and U2OS cell lines), mild in vitro antimalarial activity (against Plasmodium falciparum 3D7), as well as mild inhibitory acetylcholinesterase activity.

\section{Conclusions}

Bicyclo [6.3.0] undecane sesquiterpenoids are relatively rare in nature. From 1977 to 2018, only approximately 42 compounds with this unique scaffold were reported in terrestrial plants of the genera Asteriscus, Lippia, Cynanchum, Dumortiera, Toxicodendron, Jasonia, and Artemisia, marine organisms of the genera Aplysia, Laurencia, Capnella, Sinularia, and Phyllodesmium, and a mutant bacteria of Tubercularia sp. Their absolute configurations were determined by X-ray diffraction, Mosher's method, CD rules, ECD calculaion, biogenetic consideration, and chemical conversion methods. They can be classified into seven different types. Structurally, precapnellane, asteriscane, dumortane, toxicodenane, and capillosane feature four methyl groups on the 5-8 ring moiety, while jasionane and sinulane decorate the 
core with an isopropyl group. How the isopropyl type bicyclo [6.3.0] undecane sesquiterpenoids were formed remains a mystery, though this question may be resolved by a biosynthesis study. Because of the broad bioactivities and synthetic challenges of the cyclooctanoid core, some total synthesis works on dactylol (1), poitediol (2), precapnelladiene (3), asteriscanolide (4), and 11-hydroxyjasionone (38) were achieved to develop the methodology to prepare the cyclooctane-containing compounds. Unique structural molecules continue to be a rich source for lead compound discovery.

Author Contributions: G.-Q.L., P.-L.L., and J.-C.Y. conceived the idea and designed the review structure; H.-B.L. and F.Z. retrieved the literature and supported manuscript corrections; P.-L.L. revised the manuscript; G.-F.Q. and W.-X.L. wrote the manuscript. All authors have read and approved the final version of the manuscript.

Funding: This work was supported by the National Key Research and Development Program of China (2018YFC0310903), the National Natural Science Foundation of China (Grant No. 41876161 and 21572210), NSFC-Shandong Joint Fund for Marine Science Research Centers (Grant No. U1606403), and the Key Research and Development Plan of Shandong Province (Grant No. 2018CXGC1304).

Conflicts of Interest: The authors declare no conflict of interest.

\section{References}

1. Newman, D.J.; Cragg, G.M. Natural products as sources of new drugs from 1981 to 2014. J. Nat. Prod. 2016, 79, 629-661. [CrossRef]

2. Dias, D.A.; Urban, S.; Roessner, U. A historical overview of natural products in drug discovery. Metabolites 2012, 2, 303-336. [CrossRef] [PubMed]

3. Harvey, A.L. Natural products in drug discovery. Drug Discov. Today 2008, 13, 894-901. [CrossRef] [PubMed]

4. Mishra, B.B.; Tiwari, V.K. Natural products: An evolving role in future drug discovery. Eur. J. Med. Chem. 2011, 46, 4769-4807. [CrossRef] [PubMed]

5. Fraga, B.M. Natural sesquiterpenoids. Nat. Prod. Rep. 2013, 30, 1226-1264. [CrossRef]

6. Fraga, B.M. Natural sesquiterpenoids. Nat. Prod. Rep. 2012, 29, 1334-1366. [CrossRef] [PubMed]

7. Fraga, B.M. Natural sesquiterpenoids. Nat. Prod. Rep. 2011, 28, 1580-1610. [CrossRef] [PubMed]

8. Fraga, B.M. Natural sesquiterpenoids. Nat. Prod. Rep. 2010, 27, 1681-1708. [CrossRef]

9. Schmitz, F.J.; Hollenbeak, K.H.; Vanderah, D.J. Marine natural products: Dactylol, a new sesquiterpene alcohol from a sea hare. Tetrahedron 1978, 34, 2719-2722. [CrossRef]

10. Gadwood, R.C.; Lett, R.M.; Wissinger, J.E. Total synthesis of ( \pm )-poitediol and ( \pm )-dactylol. J. Am. Chem. Soc. 1986, 108, 6343-6350. [CrossRef]

11. Paquette, L.A.; Ham, W.H.; Dime, D.S. A formal total synthesis of dactylol. Tetrahedron Lett. 1985, 26, 4983-4986. [CrossRef]

12. Paquette, L.A.; Ham, W.H. Total synthesis of the marine sesquiterpenes dactylol and africanol. De novo construction of a cyclooctanoid natural product from cycloheptane precursors. J. Am. Chem. Soc. 1987, 109, 3025-3036. [CrossRef]

13. Feldman, K.S.; Wu, M.J.; Rotella, D.P. Application of an intramolecular tropone-alkene photocyclization to the total synthesis of ( \pm -dactylol. J. Am. Chem. Soc. 1989, 111, 6457-6458. [CrossRef]

14. Feldman, K.S.; Wu, M.J.; Rotella, D.P. Total synthesis of ( \pm )-dactylol and related studies. J. Am. Chem. Soc. 1990, 112, 8490-8496. [CrossRef]

15. Harmata, M.; Rashatasakhon, P. Intramolecular 4+3 cycloadditions. Aspects of stereocontrol in the synthesis of cyclooctanoids. A synthesis of (+)-dactylol. Org. Lett. 2000, 2, 2913-2915. [CrossRef]

16. Harmata, M. Exploration of fundamental and synthetic aspects of the intramolecular $4+3$ cycloaddition reaction. Acc. Chem. Res. 2001, 34, 595-605. [CrossRef] [PubMed]

17. Fürstner, A.; Langemann, K. A concise total synthesis of dactylol via ring closing metathesis. J. Org. Chem. 1996, 61, 8746-8749. [CrossRef]

18. Dowling, M.S.; Vanderwal, C.D. Ring-closing metathesis of allylsilanes as a flexible strategy toward cyclic terpenes. Short syntheses of teucladiol, isoteucladiol, poitediol, and dactylol and an attempted synthesis of caryophyllene. J. Org. Chem. 2010, 75, 6908-6922. [CrossRef]

19. Molander, G.A.; Eastwood, P.R. Total synthesis of (+)-dactylol via a novel [3+5] annulation approach. J. Org. Chem. 1995, 60, 4559-4565. [CrossRef] 
20. Gadwood, R.C.; Lett, R.M.; Wissinger, J.E. Total synthesis of ( \pm )-poitediol and ( \pm )-4-epipoitediol. J. Am. Chem. Soc. 1984, 106, 3869-3870. [CrossRef]

21. Dowling, M.S.; Vanderwal, C.D. Ring-closing metathesis of allylsilanes/electrophilic desilylation to prepare exo-methylidenecycloalkanes. Short syntheses of teucladial and poitediol. J. Am. Chem. Soc. 2009, 131, 15090-15091. [CrossRef]

22. Mehta, G.; Murty, A.N. Total synthesis of the marine natural product ( \pm )-precapnelladiene. J. Chem. Soc 1984, 16, 1058-1060. [CrossRef]

23. Mehta, G.; Murty, A.N. A general stereocontrolled approach to the 5-8 fused ring system. Application to the total synthesis of marine natural product ( \pm )-precapnelladiene. J. Org. Chem. 1987, 52, 2875-2881. [CrossRef]

24. Kinney, W.A.; Coghlan, M.J.; Paquette, L.A. Claisen rearrangement of 6-alkenyl-2-methylenetetrahydropyrans. A new approach to annulated 4-cyclooctenones and a stereospecific synthesis of precapnelladiene. J. Am. Chem. Soc. 1984, 106, 6868-6870. [CrossRef]

25. Kinney, W.A.; Coghlan, M.J.; Paquette, L.A. General approach to annulated 4-cyclooctenones by aliphatic Claisen rearrangement. Stereospecific total synthesis of ( \pm )-precapnelladiene. J. Am. Chem. Soc. 1985, 107, 7352-7360. [CrossRef]

26. Petasis, N.A.; Patane, M.A. A Claisen rearrangement strategy for the three-atom ring expansion of cyclic ketones. A total synthesis of ( \pm )-precapnelladiene. Tetrahedron Lett. 1990, 31, 6799-6802. [CrossRef]

27. MacDougall, J.M.; Turnbull, P.; Verma, S.K.; Moore, H.W. Synthesis of highly substituted bicyclo [3.2.0] heptanones from 3-homoallylcyclobutenones. A total synthesis of $( \pm)$-precapnelladiene. J.Org.Chem. 1997, 62, 3792-3793. [CrossRef]

28. MacDougall, J.M.; Santora, V.J.; Verma, S.K.; Turnbull, P.; Hernandez, C.R.; Moore, H.W. Cyclobutenone-based syntheses of polyquinanes and bicyclo [6.3.0] undecanes by tandem anionic oxy-Cope reactions. Total synthesis of ( \pm -precapnelladiene. J. Org. Chem. 1998, 63, 6905-6913. [CrossRef]

29. Takenaka, Y.; Ito, H.; Iguchi, K. Enantioselective formal synthesis of (+)-precapnelladiene by chiral copper-catalyzed asymmetric [2+2]-cycloaddition reaction. Tetrahedron 2007, 63, 510-513. [CrossRef]

30. Wender, P.A.; Ihle, N.C.; Correia, C.R.D. Nickel-catalyzed intramolecular [4+4] cycloadditions. 4. enantioselective total synthesis of (+)-asteriscanolide. J. Am. Chem. Soc. 1988, 110, 5904-5906. [CrossRef]

31. Paquette, L.A.; Tae, J.; Arrington, M.P.; Sadoun, A.H. Enantioselective double Michael addition/cyclization with an oxygen-centered nucleophile as the first step in a concise synthesis of natural (+)-asteriscanolide. $J$. Am. Chem. Soc. 2000, 122, 2742-2748. [CrossRef]

32. Krafft, M.E.; Cheung, Y.Y.; Juliano-Capucao, C.A. Synthesis of the first "inside-outside" eight-membered ring via ring-closing metathesis: A total synthesis of (+/-)-asteriscanolide. Synthesis 2000, 7, 1020-1026. [CrossRef]

33. Krafft, M.E.; Cheung, Y.Y.; Abboud, K.A. Total synthesis of ( \pm )-asteriscanolide. J. Org. Chem. 2001, 66, 7443-7448. [CrossRef] [PubMed]

34. Limanto, J.; Snapper, M.L. Sequential intramolecular cyclobutadiene cycloaddition, ring-opening metathesis, and Cope rearrangement: Total syntheses of (+)- and (-)-asteriscanolide. J. Am. Chem. Soc. 2000, 122, 8071-8072. [CrossRef]

35. Liang, Y.; Jiang, X.; Yu, Z.X. Enantioselective total synthesis of (+)-asteriscanolide via Rh(I)-catalyzed [(5+2)+1] reaction. Chem. Commun. 2011, 47, 6659-6661. [CrossRef] [PubMed]

36. Wang, Y.; Yu, Z.X. Rhodium-catalyzed [5+2+1] cycloaddition of the enevinylcyclopropanes and CO: Reaction design, development, application in natural product synthesis, and inspiration for developing new reactions for synthesis of eight-membered carbocycles. Acc. Chem. Res. 2015, 48, 2288-2296. [CrossRef] [PubMed]

37. Trost, B.M.; Parquette, J.R. A TMM cycloaddition strategy to the bicyclo [6.3.0] undecyl ring system. A total synthesis of 11-hydroxyjasionone. J. Org. Chem. 1994, 59, 7568-7569. [CrossRef]

38. Fenical, W.; Schulte, G.R.; Finer, J.; Clardy, J. Poitediol, a new nonisoprenoid sesquiterpene diol from the marine alga Laurencia poitei. J. Org. Chem. 1978, 43, 3628-3630. [CrossRef]

39. Ayanoglu, E.; Gebreyesus, T.; Beechan, C.M.; Djerassi, C. Terpenoids-LXXVI: Precapnelladiene, a possible biosynthetic precursor of the capnellane skeleton. Tetrahedron 1979, 35, 1035-1039. [CrossRef]

40. San Feliciano, A.; Barrero, A.F.; Medarde, M.; del Corral, J.M.; Aramburu, A. Asteriscanolide. A sesquiterpene lactone with a new natural skeleton. Tetrahedron Lett. 1985, 26, 2369-2372. [CrossRef]

41. Eldahmy, S.; Jakupovic, J.; Bohlmann, F.; Sagn, T.M. New humulene derivatives from Asteriscus graveolens. Tetrahedron Lett. 1985, 41, 309-316. [CrossRef] 
42. Catalán, C.A.N.; De Lampasona, M.E.P.; Cerda-Garcia-Rojas, C.M.; Joseph-Nathan, P. Trace constituents of Lippia integrifolia. J. Nat. Prod. 1995, 58, 1713-1717. [CrossRef]

43. Fricke, C.; Hardt, I.H.; König, W.A.; Joulain, D.; Zygadlo, J.A.; Guzmàn, C.A. Sesquiterpenes from Lippia integrifolia essential oil. J. Nat. Prod. 1999, 62, 694-696. [CrossRef]

44. Mao, S.C.; Gavagnin, M.; Mollo, E.; Guo, Y.W. A new rare asteriscane sesquiterpene and other related derivatives from the Hainan aeolid nudibranch Phyllodesmium magnum. Biochem. Syst. Ecol. 2011, 39, 408-411. [CrossRef]

45. Chen, D.W.; Chen, W.; Liu, D.; van Ofwegen, L.; Proksch, P.; Lin, W.H. Asteriscane-type sesquiterpenoids from the soft coral Sinularia capillosa. J. Nat. Prod. 2013, 76, 1753-1763. [CrossRef] [PubMed]

46. Yuan, W.P.; Cheng, S.M.; Fu, W.T.; Zhao, M.; Li, X.B.; Cai, Y.P.; Dong, J.Y.; Huang, K.X.; Gustafson, K.R.; Yan, P.C. Structurally diverse metabolites from the soft coral Sinularia verruca collected in the South China Sea. J. Nat. Prod. 2016, 79, 1124-1131. [CrossRef] [PubMed]

47. Li, J.L.; Fu, Y.; Zhang, H.Y.; Zhao, W.M. Two new humulanolides from the roots of Cynanchum wilfordii. Tetrahedron Lett. 2015, 56, 6503-6505. [CrossRef]

48. Triana, J.; Eiroa, J.L.; Morales, M.; Perez, F.J.; Brouard, I.; Quintana, J.; Ruiz-Estévez, M.; Estévez, F.; León, F. Sesquiterpenoids isolated from two species of the Asteriscus alliance. J. Nat. Prod. 2016, 79, 1292-1297. [CrossRef]

49. Toyota, M.; Bardón, A.; Kamiya, N.; Takaoka, S.; Asakawa, Y. Dumortenols, novel skeletal sesquiterpenoids from the Argentinian liverwort Dumortiera hirsuta. Chem. Pharm. Bull. 1997, 45, 2119-2121. [CrossRef]

50. Bardón, A.; Kamiya, N.; Toyota, M.; Asakawa, Y. A 7-nordumortenone and other dumortane derivatives from the Argentine liverwort Dumortiera hirsuta. Phytochemistry 1999, 51, 281-287. [CrossRef]

51. Cheng, S.Y.; Huang, K.J.; Wang, S.K.; Wen, Z.H.; Chen, P.W.; Duh, C.Y. Antiviral and anti-inflammatory metabolites from the soft coral Sinularia capillosa. J. Nat. Prod. 2010, 73, 771-775. [CrossRef]

52. Chen, D.W.; Cheng, W.; Liu, D.; van Ofwegen, L.; Proksch, P.; Lin, W.H. Capillosananes S-Z, new sesquiterpenoids from the soft coral Sinularia capillosa. Tetrahedron Lett. 2014, 55, 3077-3082. [CrossRef]

53. Lu, C.H.; Liu, S.S.; Wang, J.Y.; Wang, M.Z.; Shen, Y.M. Characterization of eight new secondary metabolites from the mutant strain G-444 of Tubercularia sp. TF5. Helv. Chim. Acta. 2014, 97, 334-344. [CrossRef]

54. He, J.B.; Luo, J.; Zhang, L.; Yan, Y.M.; Cheng, Y.X. Sesquiterpenoids with new carbon skeletons from the resin of Toxicodendron vernicifluum as new types of extracellular matrix inhibitors. Org. Lett. 2013, 15, 3602-3605. [CrossRef] [PubMed]

55. Dewick, P.M. Medicinal Natural Products: A Biosynthetic Approach, 3rd ed.; John Wiley and Sons: West Sussex, UK, 2002; pp. 14-16, 210-217. [CrossRef]

56. Qin, G.F.; Tang, X.L.; Sun, Y.T.; Luo, X.C.; Zhang, J.; van Ofwegen, L.; Sung, P.J.; Li, P.L.; Li, G.Q. Terpenoids from the soft coral Sinularia sp. collected in Yongxing Island. Mar. Drugs 2018, 16, 127. [CrossRef] [PubMed]

57. Ahmed, A.A.; Jakupovic, J.; Eid, F.; Ali, A.A. 11-Hydroxyjasionone, a new sesquiterpene type from Jasonia montana. Phytochemistry 1988, 27, 3875-3877. [CrossRef]

58. Rustaiyan, A.; Sigari, H.; Jakupovic, J.; Grenz, M. A sesquiterpene lactone from Artemisia diffusa. Phytochemistry 1989, 28, 2723-2725. [CrossRef]

59. Noori, S.; Taghikhani, M.; Hassan, Z.M.; Allameh, A.; Mostafaei, A. Tehranolide could shift the immune response towards Th1 and modulate the intra-tumor infiltrated T regulatory cells. Iran. J. Immunol. 2009, 6, 216-224.

60. Noori, S.; Taghikhani, M.; Hassan, Z.M.; Allameha, A.; Mostafaei, A. Tehranolide molecule modulates the immune response, reduce regulatory $\mathrm{T}$ cell and inhibits tumor growth in vivo. Mol. Immunol. 2010, 47, 1579-1584. [CrossRef]

61. Noori, S.; Hassan, Z.M. Tehranolide inhibits proliferation of MCF-7 human breast cancer cells by inducing G0/G1 arrest and apoptosis. Free Radic. Bio. Med. 2012, 52, 1987-1999. [CrossRef]

62. Noori, S.; Hassan, Z.M. Tehranolide inhibits cell proliferation via calmodulin inhibition, PDE, and PKA activation. Tumour Biol. 2014, 35, 257-264. [CrossRef]

63. Taherkhani, M. Mutagenic, anti-mutagenic and cytotoxic activities of artediffusin (tehranolide), in vitro, extracted from Artemisia diffusa. Iran. J. Toxicol. 2015, 9, 1316-1321.

64. Rustaiyan, A.; Nahrevanian, H.; Kazemi, M. Isolation of artediffusin (tehranolide) as a new antimalarial agent. Asian J. Chem. 2011, 23, 4810-4814. 
65. Rustaiyan, A.; Nahrevanian, H.; Zamani, Z.; Taherkhani, M.; Iravani, A. An investigation on anti-malarial effects of tehranolide isolated from Artemisia diffusa against human malaria parasite, Plasmodium falciparum in vitro. Res. J. Parasitol. 2015, 10, 73-78. [CrossRef]

66. Rustaiyan, A.; Nahrevanian, H.; Kazemi, M. A new antimalarial agent; effect of extracts of Artemisia diffusa against Plasmodium berghei. Pharm. Mag. 2009, 4, 1-7. [CrossRef]

67. Taherkhani, M.; Rustaiyan, A.; Nahrevanian, H. Effect of extracts of Artemisia diffusa against Plasmodium berghei. Asian J. Chem. 2012, 24, 1591-1595.

68. Tian, S.H.; Chai, X.Y.; Zan, K.; Zeng, K.W.; Guo, X.Y.; Jiang, Y.; Tu, P.F. Arvestolides A-C, new rare sesquiterpenes from the aerial parts of Artemisia vestita. Tetrahedron Lett. 2013, 54, 5035-5038. [CrossRef]

Sample Availability: Not available.

(C) 2019 by the authors. Licensee MDPI, Basel, Switzerland. This article is an open access article distributed under the terms and conditions of the Creative Commons Attribution (CC BY) license (http://creativecommons.org/licenses/by/4.0/). 